\title{
The Current Legal Provisions on Electronic Records and Electronic Archives in Vietnam
}

\author{
THI HOA DOAN, PH.D. \\ Head of Department of Science Management and Post-Graduate Study, Hanoi University of Home Affairs, \\ No.36 Xuan La, Xuan La Ward, Tay Ho District, Hanoi, Vietnam \\ e-mail: hoadhnv@gmail.com
}

\begin{abstract}
The Current Legal Provisions on Electronic Records and Electronic Archives in Vietnam
\end{abstract}

$$
\text { ABSTRACT }
$$

This paper presents the provisions of Vietnamese law on electronic records and electronic document archives and focuses on the following issues: The provisions of Vietnamese law on electronic records (definition, legal validity, regulations on digital signatures, amendments in the socio-economic fields which shall be adequate for the use of electronic records in the activities of state agencies); The provisions of Vietnamese law on electronic archives (State management responsibilities for electronic document archives); Regulations on electronic archives' activities (collection, value identification, preservation, protection, usage, and destruction when they have no further value to exploit). In conclusion the Comments on the achievements and future direction for electronic archives are presented.

Key words: Vietnam; Hanoi; electronic records, electronic archives; Law on E-Transactions; Law on Archives; Decree No.01/2013/ND-CP

Provvedimenti legali su documenti elettronici ed archivi di documenti elettronici in Vietnam

\section{SINTESI}

Questo intervento presenta le disposizioni della legislazione vietnamita sui documenti elettronici e gli archivi elettronici, e si concentra sui seguenti aspetti: le disposizioni della legge vietnamita sui documenti elettronici (definizione, validità legale, regolamenti sulle firme digitali, emendamenti nei settori socioeconomici che saranno adeguati all'utilizzo di registrazioni elettroniche nelle attività delle agenzie statali); le disposizioni della legge vietnamita sugli archivi elettronici (responsabilità di gestione dello Stato per archivi di documenti elettronici); i regolamenti sulle attività dell'archivio elettronico (raccolta, identificazione dei valori, conservazione, protezione, uso e distruzione quando non abbiano più ulteriori valori da sfruttare). In conclusione, vengono presentati i commenti sui risultati e sulla direzione futura degli archivi elettronici.

Parole chiave: Vietnam, Hanoi, documenti elettronici, archivi elettronici Legge sulle transazioni elettroniche, Legge sugli archivi, Decreto n. 01/2013/ND-CP

Aktualne pravne določbe o elektronskem arhivskem gradivu in elektronskem arhivu v Vietnamu

$$
\text { IZVLE ¿̌EK }
$$

V prispevku so predstavljene določbe vietnamskega zakona o elektronskem arhivskem gradivu in elektronskem arhivu, ki se osredotočajo na naslednja vprašanja: Določbe vietnamskega zakona o elektronskem arhivskem gradivu (opredelitev, pravna veljavnost, predpisi o digitalnih podpisih, spremembe na socialno-ekonomskih področjih ki vplivajo na uporabo elektronskega arhivskega gradiva državnih organov); določbe vietnamskega zakona o elektronskem arhivu (odgovornosti državne uprave za elektronski arhiv); uredbe o dejavnostih arhiviranja elektronskega arhivskega gradiva (zbiranje, valorizacija, ohranjanje, zaščita, uporaba in uničenje, če nimajo arhivske vrednosti). V zaključku so predstavljenena razmišljanja o dosežkih in prihodnjih usmeritvah glede elektronskega arhivskega gradiva.

Ključne besede: Vietnam, Hanoi, elektronsko arhivsko gradivo, elektronski arhiv, Zakon o elektronskem poslovanju, Zakon o arhivih, Uredba No.01/2013/ND-CP 
Thi Hoa DOAN: The Current Legal Provisions on Electronic Records and Electronic Archives in Vietnam, 99-105

\section{NHƯNGG QUY ĐỊNH CỦA PHÁP LUÂT VỀ TÀI LIỆU ĐIỆN TỬ VÀ LƯU TRƯ TÀI LIỆU ĐIỆN TỬ Ở VIỆT NAM HIỆN NAY}

\section{TÓM TĂT}

Bài viết giới thiệu về những quy định của pháp luật Việt Nam về tài liệu điện tử và lưu trữ tài liệu điện tử. Tác giả sẽ tập trung làm rõ những vấn đề sau đây:

- Nhửng quy định của pháp luật Việt Nam về tài liệu điện tử: khái niệm tài liệu điện tử, giá trị pháp lý của tài liệu điện tử, quy định về chữ ký số, nhửng điều chỉnh pháp luật trong các lính vực kinh tế-xã hội cơ bản cho phù hợp với vấn đề sử dụng tài liệu điện tử trong hoạt động của các cơ quan nhà nước

- Những quy định của Pháp luật Việt Nam vể lưu trữ tài liệu điện tử:

+ Về trách nhiệm quản lý nhà nước trong lưu trữ tài liệu điện tử;

+ Quy định của pháp luật về các nghiệp vụ lưu trữ tài liệu điện tử: về thu thập, xác định giá trị tài liệu điện tử, bảo quản và bảo vệ an toàn tài liệu lưu trữ điện tử, hủy tài liệu hết giá trị và khai thác, sử dụng tài liệu điện tử;

- Kết luận: Nhận xét về những thành tựu đã đạt được và định hướng trong thời gian tới đối với vấn để lưu trữ tài liệu điện tử.

Key words: Vietnam; Hà Nội; tài liệu điện tử, tài liệu lưu trữ điện tử; Luật Giao dịch điện tử; Luật Lưu trữ: Nghị định số 01/2013/NĐ-CP

Since the beginning time of information technology (IT) application to date, Vietnam has developed a system of legal documents which directly or indirectly regulates e-transaction. It affirms the legal validity of electronic records as well as creates a legal mechanism to guarantee the long-term archiving and promotes the value of electronic archives.

In order to have the basis of IT application for the current management activities of agencies, organizations, and individuals, the Law on E-transactions was passed by the National Assembly in 2005. Then, the Law on Information Technology and Law on Archives were promulgated in 2006 and 2011, respectively. These laws and some sub-law documents presently constitute a regulatory framework of e-transaction, management, and archives of electronic records in Vietnam.

\section{Vietnam's regulations on the legal validity of electronic records}

The Vietnam Law on E-Transactions (2005) is the first specialized law in the field of information technology. The Law consists of 08 chapters and 54 articles, covering most of the important issues in E-transactions. The provisions of the law also give a legal foundation for electronic records which is the basis of electronic records existing on various types of electronic transactions. First of all, the law defines that data message (of electronic records) is "information that is created, sent, received and stored electronically". That data message is as valid as the text "if the information contained in that data message is accessible and usable for reference when necessary" (Article 12) and the data message is as valid as the original one (Article 13) when the following conditions are met:

+ The content of the data message is guaranteed as safe from its initial creation as a complete data message. The content of the data message is considered to be complete when such content has not been altered, except for changes in form arising in the course of sending, storing or displaying data messages;

+ The content of data message is accessible and usable in a complete form when necessary.

Article 14 of the Law stipulates that data message is as valuable as evidence and the evidential value of data message "is based on the reliability of the method to initialize, archive or transmit data message; the method to guarantee and maintain the integrity of the data message; the method to identify the originator and other relevant factors."

Thus, the legal validity of electronic records mainly depends on two things: ensuring the integrity of records and archiving documents electronically for search and reference purpose when necessary. Once 
Thi Hoa DOAN: The Current Legal Provisions on Electronic Records and Electronic Archives in Vietnam, 99-105

the integrity of the electronic records has been guaranteed, the electronic records shall be as valid as evidence and as legally valid as paper records. The electronic signature is used to guarantee the integrity, the authenticity and the legal nature of the text. The Law devotes all 03 chapters ( 11 articles) to regulate electronic signatures and adjust some issues such as the legal validity of electronic signatures, the conditions for an electronic signature to be valid, the security of electronic signatures, the obligations of the parties signing the electronic signatures and the parties accepting electronic signatures, the certification of electronic signatures. The Law also stipulates the conditions that make foreign electronic signatures and electronic certifications be accepted in Vietnam.

The Law on E-Transactions (2005) also regulates the security and safety of electronic transactions, the mutual commitment to the electronic contract, e-transactions in state administrative agencies, the intellectual property, and copyrights of e-transactions, electronic archives. The basic spirit of the Law is the recognition of the legal validity of electronic records, the recognition of a new form of expression in civil transactions by means of data messages, i.e. recognizing the legal validity of electronic transactions.

After the introduction of the Law on E-Transactions, the Government of Vietnam rapidly promulgated a series of sub-legal documents and Decrees guiding the implementation of the Law on E-Transactions. A typical example is the Decree No.26/2007/ND-CP "detailing the implementation of the Law on e-transactions of digital signatures and digital signature certification service" dated 15 February 2007. Hence, though the issues of electronic signatures are stated by many articles in the Law on E-Transactions, the Government of Vietnam has enacted a separate decree regulating electronic signatures. The Decree consists of 11 chapters and 73 articles, detailing the concept of digital signatures, the legal validity of digital signatures, the digital signature provision and certification service, the state management responsibilities of the digital signature provision and certification service, the rights and obligations of the providers and users of digital signatures.

In addition to the Decree No.26/2007/ND-CP (2006), the Government of Vietnam has issued a number of Decrees which adjust electronic transaction activities in some important socio-economic fields, namely:

- Decree No.57/2006/ND-CP on E-Commerce dated 09 June 2006;

- Decree No.27/2007/ND-CP on E-Transactions in Financial Activities dated 23 February 2007;

- Decree No.35/2007/ND-CP on Banking E-Transactions dated 08 March 2007.

The Decree No.57/2006/ND-CP on E-Commerce (2006) regulates the use of electronic vouchers in commercial activities and activities related to trade within and outside the territory of Vietnam and the legal validity of electronic vouchers. The Decree No.35/2007/ND-CP on banking e-transactions (2007) has reserved Chapter 3 on electronic vouchers in banking activities, which stipulates in detail on format standards, principles of creation, control, form, preservation, storage and destruction of electronic vouchers. This is a decree with detailed and feasible regulations on the management and storage of electronic vouchers of a sector. Chapter 2 of Decree No.27/2007/ND-CP on e-transactions in financial activities (2007) specifies electronic vouchers in terms of management, destruction, sealing and temporarily holding and confiscation. These decrees and circulars have created a breakthrough in e-commerce, online taxation, e-customs, e-securities, e-payments and online banking in Vietnam.

On December 2008, the Prime Minister of Vietnam issued the Directive No.34/2008/CT-TTg on promoting the use of the e-mail system in the activities of state agencies (2008). According to the Directive, the records transmitted through e-mail system in compliance with the provisions of the law on e-transactions have legal validity equivalent to paper records in transactions among state agencies and the sending agencies do not have to send extra paper records. The incoming records which are transferred via e-mail system in order that the agencies and organizations can receive and handle as paper records must satisfy the provisions of the Law on E-Transactions No.51/2005/QH11 (2005). Apart from the general provisions, the documents must meet the specific requirements written in the Law on E-Transactions (2005) including Article 11 - the legal validity of data message; Article 12 - the data message is as valid as text; Article 13 - the data message is as valid as the original; Article 14 - the data message is valuable as evidence, in case where the compilation of dossiers for archives is required, the documents must comply with specifications in Article 15 on data message archives. 
Thi Hoa DOAN: The Current Legal Provisions on Electronic Records and Electronic Archives in Vietnam, 99-105

Additionally, on 22 May 2012, the Prime Minister of Vietnam issued the Directive No.15/CT-T$\mathrm{Tg}$ on promoting the use of e-records in the activities of state agencies (2012). By this Directive, the Prime Minister has requested the Ministry of Home Affairs to coordinate with the Ministry of Information and Communication, the Government Office to propose new development, or amendment and supplementation of the legal documents to promote the use of electronic records in the activities of state agencies; to be in charge of drafting regulations on electronic archives.

The introduction of a series of above legal documents emphasizes the value of electronic records, enhancing the applicability of this new type of document and its existence and dominance to various activities of agencies or organizations. Besides, a new type of document - electronic archives has just appeared in the field of archives. Among archival activities, Vietnam has timely issued and adjusted the legal document system to meet the practical requirements.

\section{Vietnam's regulations on electronic archives}

In 2011, Vietnam was moving up administrative reform with the main content of "administrative modernization" to improve and promote the operation of the Government's electronic information network on the internet, with the goal of achieving by 2020: "90\% of official documents sent and received in state administrative agencies are electronic... Most transactions of state administrative agencies are conducted in an electronic environment anytime and anywhere based on multimedia; most of the public services are provided online..." (Resolution No.30c/NQ-CP, 2011), the Government of Vietnam has passed the Law of Archives. Recognizing the increase of electronic records in the activities of agencies and organizations leading to the increase of electronic archives, the Law on Archives also comprises articles of electronic archives management. As specified by Article 13 of the Law:

- Electronic archives are documents created in the form of data message found in the course of operation of selected organizations, agencies, individuals for archives or digitalized from archival documents on other information objects.

- Electronic archives must meet the standards of data input, assuring the legacy, integrity, authenticity, security and accessibility; to be preserved and used in a professional manner.

In this way, the Vietnam Law on Archives acknowledges electronic archives as being "data messages" which are initiated in the activities of agencies and organizations. The conditions and legal basis of the data message have been clearly defined in the Law on E-Transactions (2005). The provisions of the Law on E-Transactions (2005) and the Law on Archives (2011) have created the unity in the legal system of Vietnam on electronic records. After the promulgation of the Law on Archives (2011), the Government of Vietnam also promptly issued the Decree No.01/2013/ND-CP (2013) providing in details a number of articles of the Law on Archives (hereinafter referred to as Decree No.01/2013/ND-CP), important sub-law documents, detailed provisions on the legal validity and electronic archives issues. These regulations are:

\subsection{Responsibilities of managing and archiving electronic records}

Most of the content of the Decree No.01/2013/ND-CP (2013) regulates the management of electronic archives and protection of electronic information sources. Article 13 of the Decree clearly stipulates that Ministry of Home Affairs, the state management agency of Vietnam archives, is responsible for managing electronic archives and developing regulations and guidelines for electronic records archival profession. Historical archives are responsible for carrying out archival operations for electronic archives in accordance with the legal provisions of archives.

\subsection{Legal validity of electronic archives}

One of the important values of archives is the value of evidence. As the technological characteristics of electronic records are easy to change and copy, it is necessary to have specific provisions to guarantee the legality of becoming electronic archives, the Decree No.01/2013/ND-CP (2013) has evidently defined input data "which is information describing the characteristics of documents such as content, author, time, format, quality, condition and other characteristics to facilitate the process of collecting, preserving, searching, accessing, managing and storing data". According to articles of the Decree, electronic archives 
Thi Hoa DOAN: The Current Legal Provisions on Electronic Records and Electronic Archives in Vietnam, 99-105

shall be as valid as the original one if they are determined following the regulated archival profession and ensured in terms of the reliability, integrity, authenticity and accessibility of information in documents as from the initial creation as a complete data message.

As follows, the provisions of the Vietnam Law on E-Transactions (2005), Law on Archives (2011) on electronic archives management and the provisions of the Decree No.01/2013/ND-CP (2013) have confirmed the legal value of electronic records not only in the current stage but also throughout the document life cycle.

\subsection{Regulations on implementation of archival profession for electronic records}

Electronic records shall be as valid as paper documents in terms of legality and historical value if they meet the legal requirements of the integrity, authenticity, and accessibility. Like other countries in the world, Vietnam is making great effort to find solutions to long-term storage of electronic document resources for various purposes and to maximize their value. However, in order for electronic archives to meet all requirements of the traditional archival profession as well as of technology, it is necessary to establish a legal mechanism as the basis for related activities. The provisions of Decree No.01/2013/ND-CP (2013) stipulate basic issues regarding the implementation of the archival profession for electronic records. Article 4 of the Decree regulates that "Electronic archives are formed in the activities of agencies, organizations should be compiled, selected and preserved in obedience to archival profession and IT techniques in the electronic document management system" and the person who directly supervises and handles the work shall be responsible for conducting all regulations on creating managing, recording and submitting electronic records to archives (Article 13). When it comes to technology, the Decree stipulates "the electronic document management system must meet the technical requirements so the electronic archives are authentic, complete, consistent, secure information, accessible from the first creation". The implementation of the archival profession for electronic records is specified as follows:

\subsubsection{Electronic records collection}

The provisions of Decree No.01/2013/ND-CP (2013) clearly stipulate the process and standards of electronic records when transferred into historical archives and the responsibilities of the archives " When receiving electronic archives, archives and historical archives must check the authenticity, integrity, and accessibility of the documents. The documents must ensure the content, structure, and context and be protected from damage, destruction, correction or data lost" (Article 7).

\subsubsection{Method to determine the value of electronic records}

Pursuant to the provisions of the Law on E-Transactions (2005) and Law on Archives (2011), there are sufficient legal foundations in Vietnam for electronic records to be recognized as valid as paper records. As such, electronic archives are as valuable as paper records and archival profession for paper records should be applied to electronic records when these records are transferred to archives. With regard to valuation issues, Decree No.01/2013/ND-CP (2013) states that "electronic archives shall be valued according to the principles, methods, and criteria of content valuation as archival documents on other information objects and must meet the following requirements:

a. Ensure the reliability, integrity, and authenticity of the information contained in the electronic records since that document was first initialized as a complete data message;

$b$. The information contained in electronic archives can be accessible, usable in a complete form".

\subsubsection{Regulations on preservation and protection of electronic archives}

Unlike paper records, the preservation and protection of electronic archives are more complex due to technological issues. As stated by the Decree No.01/2013/ND-CP (2013), the Government of Vietnam stipulates that electronic archives must be stored safely and converted by suitable technology. The archives agencies must regularly check, and make a backup in order to guarantee the safety, integrity, and accessibility of electronic archives and to use technical measures to classify and store smoothly but to make sure that the contents of the document are not changed. The Decree also states clearly that the means of storing electronic archives must be kept in an appropriate archival environment. 
Thi Hoa DOAN: The Current Legal Provisions on Electronic Records and Electronic Archives in Vietnam, 99-105

The law of Vietnam also set out that archival agencies are required to be accountable for periodic inspection and security assurance of the electronic document management system, taking measures to guarantee security, safety, and confidentiality in line with the law (Article 10). It is strictly forbidden to illegally access, alter, tamper, copy, disclose, send, destroy electronic archives, create or distribute software programs that disturb, alter and destroy the operating system or commit other acts to undermine the management means of electronic archives (Article 12).

\subsubsection{The use and destruction of electronic archives when out of use}

The provisions of Decree No.01/2013/ND-CP (2013) also specify both the use and destruction of electronic archives if out of use. According to the provisions of the Decree, electronic archives in Vietnam are exploited, used as documents on other information objects and must strictly comply with all provisions of law. With regard to the destruction of electronic archives, all information must be destroyed (Article 11).

\section{Conclusion}

It can be seen that Vietnam has developed a legal foundation for electronic records. The Law on E-transactions (2005), the Decree on Digital Signatures (2007) and the system of related legal documents have created a legal mechanism for the existence of electronic records. An electronic transaction is asserted as a convenient, fast and efficient way of transmitting information where data messages have the same legal validity as paper documents. This legal document system is the legal basis to create favorable conditions for electronic records to gradually become popular in all fields in Vietnam. The Vietnam Law on Archives (2011) and the Decree No.01/2003/ND-CP (2013) continue to contain detailed and clear provisions on electronic archives as a basis for long-term archives, preservation and effective use of this new source. At present, Vietnam continues to implement these laws into practices, especially in archives, developing policies as well as optimal approaches for electronic records archives.

\section{References}

Decree detailing the implementation of the Law on e-transactions of digital signatures and digital signature certification service (2007 February 15). The Government of the Socialist Republic of Vietnam, No.26/2007/ND-CP.

Decree on Banking E-Transactions (2007 March 08). The Government of the Socialist Republic of Vietnam, No.35/2007/ND-CP.

Decree on E-Commerce (2006 June 09). The Government of the Socialist Republic of Vietnam, No. 57/2006/ ND-CP.

Decree on E-Transactions in Financial Activities (2007 February 23). The Government of the Socialist Republic of Vietnam, No.27/2007/ND-CP.

Decree on Information Technology Application in State Agencies Operations (2007 April 10). The Government of the Socialist Republic of Vietnam, No.64/2007/ND-CP.

Decree providing in details a number of articles of the Law on Archives (2013 January 03). The Government of the Socialist Republic of Vietnam, No.01/2013/ND-CP.

Directive on promoting the use of e-documents in the activities of state agencies (2012 May 22). The Prime Minister of the Socialist Republic of Vietnam, No.15/CT-TTg.

Directive on promoting the use of the e-mail system in the activities of state agencies (2008 December 03). The Prime Minister of the Socialist Republic Of Vietnam, No.34/2008/CT-TTg.

Law on Archives (2011 November 11). The National Assembly of the Socialist Republic of Vietnam, No.01/2011/ $\mathrm{QH} 13$.

Law on E-transactions (2005 November 29). The National Assembly of the Socialist Republic of Vietnam, No.51/2005/QH11.

Law on Information Technology (2006 June 29). The National Assembly of the Socialist Republic of Vietnam, No.67/2006/QH11.

Resolution promulgating the Master Program on State Administration Reform in the 2011-2020 period (2011 November 08). The Government of the Socialist Republic of Vietnam, No.30c/NQ-CP. 
Thi Hoa DOAN: The Current Legal Provisions on Electronic Records and Electronic Archives in Vietnam, 99-105

\section{SUMMARY}

Like other countries in the world, in Vietnam, information technology has penetrated into every aspect of social life. Electronic records are now available in all organizations and agencies' activities and are gradually replacing paper records. Therefore, Vietnam has promulgated legal documents and amendments linked with electronic records and electronic archives. These are Law on E-transactions, Law on Information Technology, Law on Archives, Decree on Digital Signatures, Decree providing in details a number of articles of the Law on Archives (the main content is about electronic records archives) and some other decrees adjusting related topics. This system of legal documents regulates the following issues:

- Legal validity of electronic records: conditions for electronic records to be valid as paper documents and original documents and having evidential value, etc.

- Detailed provisions on digital signatures: the legal validity of digital signatures, digital signature certification service, rights and obligations of digital signature providers and users, etc.

- Provisions on electronic records archives. Vietnam Ministry of Home Affairs is responsible for direct state management for electronic records archives. The mentioned laws also stipulate in details, for instance, the legal validity of electronic archives, archival profession including collecting, valuing, preserving, protecting, using and destructing electronic records (if out of use), etc.

These legal documents have created a legal mechanism for electronic records to come into reality in Vietnam as a basis for long-term archives and maximizing their value.

Typology: 1.02 Review Article

Submitting date: 06.04.2017

Acceptance date: 05.05.2017 